\title{
Oil-in-water Emulsion Breaking by Electrocoagulation in a Modified Electrochemical Cell
}

\author{
M. H. Abdel-Aziz ${ }^{1,2}$, E-S. Z. El-Ashtoukhy ${ }^{2, *}$, M. Sh. Zoromba ${ }^{1,3}$, M. Bassyouni, ${ }^{1,4}$ \\ ${ }^{1}$ Chemical and Materials Engineering Department, King Abdulaziz University, Rabigh, Saudi Arabia \\ ${ }^{2}$ Chemical Engineering Department, Faculty of Engineering, Alexandria University, Alexandria, \\ Egypt \\ ${ }^{3}$ Department of Chemistry, Faculty of Science, Port Said University, Port Said, Egypt. \\ ${ }^{4}$ Department of Chemical Engineering, Higher Technological Institute, Tenth of Ramdan City, Egypt \\ *E-mail: elsayed_elashtoukhy@ hotmail.com
}

doi: $10.20964 / 2016.11 .53$

Received: 26 July 2016 / Accepted: 11 September 2016 / Published: 10 October 2016

Separation of oil from oil-in-water $(\mathrm{O} / \mathrm{W})$ emulsion using the electrocoagulation technique was investigated in an electrochemical cell employing new anode geometry. The anode was a horizontal coiled aluminum cylinder with an outer diameter of $1 \mathrm{~cm}$ and $0.5 \mathrm{~cm}$ gap between turns, the cathode was a horizontal $\mathrm{Al}$ disc placed at the bottom of the cell. The present anode geometry allows the use of the anode outer surface for electrocoagulation and the inner surface as a heat exchange facility to control the solution temperature. Variables studied are applied current density, electrolyte conductivity, initial $\mathrm{pH}$ of the electrolyte and initial oil concentration. Within the range of parameters studied, the \% removal was found to increase with increasing current density, solution conductivity and initial $\mathrm{pH}$ in the range (3-8) with the increase in initial oil concentration has a negative effect on the \% removal. In order to optimize (technical and economical) the parameters of the present study, electrical energy consumption $\left(\mathrm{kW} \cdot \mathrm{h} / \mathrm{m}^{3}\right)$ was calculated at various operating conditions.

Keywords: Electrocoagulation; Wastewater; Emulsion; Oil removal

\section{FULL TEXT}

(C) 2016 The Authors. Published by ESG (www.electrochemsci.org). This article is an open access article distributed under the terms and conditions of the Creative Commons Attribution license (http://creativecommons.org/licenses/by/4.0/). 